\title{
A study of the influence of the base thickness on photoelectric parameters of silicon solar cells with the new TCAD algorithms
}

Murodjon K. Abduvohidov ${ }^{\bowtie}$, Rayimjon Aliev², Jasurbek Gulomov ${ }^{3}$

1,2,3 Andijan State University, Andijan, 170100, Uzbekistan

1 maueraa@gmail.com ${ }^{\bowtie}$, https://orcid.org/0000-0002-7598-8565

2 alievuz@yahoo.com, https://orcid.org/0000-0003-1986-2199

3 jasurbekgulomov@yahoo.com, https://orcid.org/0000-0001-7516-987X

\section{Abstract}

The Sentaurus TCAD software package is widely used in the modeling of semiconductor optoelectronic devices. The main part of simulating solar elements is creating a correct geometric model. A geometric model can be built using the SDE module in two different ways, i.e. by writing code or using standard shapes in a graphical environment. Creating complex structures using simple shapes is time-consuming and labour intensive. Therefore, this paper provides data on how to develop algorithms using geometric models of complex structural solar cells. A universal algorithm has been developed for creating a geometric model of solar cells with a sinusoidal $p$ - $n$ junction and a rear multiple structure. Using these algorithms, it is possible to create geometric models of various solar cells from simple to complex structures. By applying this algorithm, the authors studied the dependence of photoelectric parameters of the $p-n$ and $n-p$ junction silicon solar cells on their thickness in order to find the optimum thickness for both structures. It has been found, that the optimum thickness was equal to $256 \mu \mathrm{m}$ for $p$ - $n$ junction and $75 \mu \mathrm{m}$ for $n-p$ junction silicon solar cell. The maximum efficiency of $p$ - $n$ junction silicon solar cell is 1.4 times greater than that of $n-p$ junction solar cell in their optimum thickness.

Keywords

Sentaurus TCAD, SDE, structure, algorithm, modeling, solar cell, silicon, junction, thickness

Acknowledgements

The authors are grateful to the staff of the Renewable Energy Sources Laboratory at Andijan State University for their close assistance in preparing this article.

For citation: Abduvohidov M.K., Aliev R., Gulomov J. A study of the influence of the base thickness on photoelectric parameters of silicon solar cells with the new TCAD algorithms. Scientific and Technical Journal of Information Technologies, Mechanics and Optics, 2021, vol. 21, no. 5, pp. 774-784. doi: 10.17586/2226-1494-2021-21-5-774-784

\section{УДК 621.382}

\section{Исследование влияния толщины базы на фотоэлектрические параметры кремниевых солнечных элементов с использованием новых TCAD алгоритмов}

\author{
Муроджон Комилович Абдувохидов $1 \bowtie$, Райимжон Алиев ${ }^{2}$, Жасурбек Гуломов 3
}

1,2,3 Андижанский государственный университет, Андижан, 170100, Узбекистан

1 maueraa@gmail.com ${ }^{\bowtie}$, https://orcid.org/0000-0002-7598-8565

2 alievuz@yahoo.com, https://orcid.org/0000-0003-1986-2199

3 jasurbekgulomov@yahoo.com, https://orcid.org/0000-0001-7516-987X

\section{Аннотация}

Программный пакет Sentaurus TCAD широко используется при моделировании полупроводниковых оптоэлектронных устройств. Основную часть моделирования солнечных элементов составляет разработка правильной геометрической модели. Модель можно разработать, используя модуль SDE двумя разными 
способами: путем написания кода или применения стандартных форм в графической среде. Разработка сложных конструкций солнечных элементов с использованием простых форм занимает много времени и является трудоемкой. В работе выполнено исследование разработок новых алгоритмов создания геометрических моделей солнечных элементов со сложными конструкционными структурами. Разработан универсальный алгоритм солнечных элементов с синусоидальным фронтом $p-n$ перехода и задней мульти-переходной структурой. Используя алгоритм, можно создать модели солнечных элементов от простых до сложных конструкций. Изучена зависимость фотоэлектрических параметров кремниевых солнечных элементов с $p$ - $n$ и $n-p$ переходами от толщины базы с целью выбора оптимальной толщины для каждого из рассмотренных структур. Установлено, что оптимальная толщина базы составляет 256 мкм для структуры с $p$ - $n$ перехода и 75 мкм - с $n-p$ переходом. Максимальный КПД кремниевых солнечных элементов при выборе толщины базы с $p$ - $n$ переходом в 1,4 раза больше, чем с $n-p$ переходом.

\section{Ключевые слова}

Sentaurus TCAD, структура, алгоритм, моделирование, солнечная батарея, кремний, переход, толщина

\section{Благодарности}

Авторы выражают благодарность сотрудникам Лаборатории возобновляемых источников энергии Андижанского государственного университета за их активную помощь в подготовке этой статьи.

Ссылка для цитирования: Абдувохидов М.К., Алиев Р., Гуломов Ж. Исследование влияния толщины базы на фотоэлектрические параметры кремниевых солнечных элементов с использованием новых TCAD алгоритмов // Научно-технический вестник информационных технологий, механики и оптики. 2021. Т. 21, № 5. С. 774-784 (на англ. яз.). doi: 10.17586/2226-1494-2021-21-5-774-784

\section{Introduction}

The rapid development of information technologies helped to create the new method of instrumental and technological modeling to design and study semiconductor microelectronic devices. The new method helps to save materials and labor resources and reduce the duration of research to develop new devices or improve their properties. The development of nanoelectronics shows relevance of using this new method. Nanotechnology is intensively introduced to develop third-generation semiconductor solar cells (SCs). Especially, scientists can expand the possibilities of software-technological modeling by improving algorithms that are more suitable for the defined tasks of software systems.

Last 20 years, various digital technological platforms for modeling semiconductor devices have appeared. We can name, for example, the PV Lighthouse simulator, the Silvaco TCAD system, the COMSOL Multiphysics ${ }^{\circledR}$ package, the Sentaurus TCAD system, and many others. The "PV Lighthouse" simulator is a more suitable tool for modeling the solar cell structure. However, the capabilities of this system are limited than of other software systems that are listed above. For instance, by using the "PV Lighthouse" simulator, it is possible to simulate only the classical design of solar cells with a flat $p-n$ junction but, to model more complex structures such as multijunction solar cells, especially in nanoscale, is practically impossible.

Comparative analysis of the capabilities of modeling software shows that the "Sentaurus TCAD" system has advantages for modeling SCs containing nanotechnological structural elements. Therefore, in this work, the licensed software system "Sentaurus TCAD" was used for modeling the silicon SCs $[1,2]$. Sentaurus is a TCAD toolbox that simulates the operation principles and properties of microelectronic and nano-electronic semiconductor devices. In Sentaurus TCAD, physical models are used to study wafer fabrication and device operation and optimize the designs and parameters of new semiconductor devices.
The nanoparticles introduced silicon solar cells were simulated by using Sentaurus TCAD $[3,4]$. It contains numerous working software packages with vast capabilities. SDE, Sentaurus Device, SVisual packages and Sentaurus Workbench framework are used to model SC. SDE is a 2D/3D device editor that builds and edits device structures by using geometric operations. Consequently, the role of SDE in the creation of new designs of solar cells is very significant. Algorithms for creating new device structures in the SDE module of the Sentaurus TCAD system are the main part of modeling.

A separate algorithm for each semiconductor device design can be created in the traditional way. But, if one pays attention to the designs of new and more advanced solar cell structures, one can see similar structural elements, repeating in structure and differing in quantitative parameters. Therefore, it is significant to conduct research on the development of more universal algorithms with wide functionality. In the present work, an algorithm has been developed to simulate a complex of similar structures of silicon solar cells by using the SDE module of the "Sentaurus TCAD" system.

\section{Method}

The algorithm of modeling a sequence of simple silicon-based SC has been developed, as shown in Fig. 1. In algorithm, SC components are given: silicon; $p$-type; $n$-type; contact. Also, the width $\left(f_{c_{-}} l, b c_{-} l, d_{-} l\right)$ and thickness $\left(f_{c} \_t h, n_{-} t h, p_{-} t h, b c_{-} t h\right)$ of the solar cell are determined based on its coordinates in the Cartesian system on the plane.

The graphical designer called "Sentaurus Structure Editor" (module SDE) is used to build up the geometric model of the SC. The module SDE is loaded with a graphical editing window. The "Silicon" element is selected from the toolbar. $p, n$, and contact regions are drawn by selecting rectangle shape from the toolbar. By entering the corresponding section of the menu, the contacts are activated and set to $n$ and $p$ regions. 


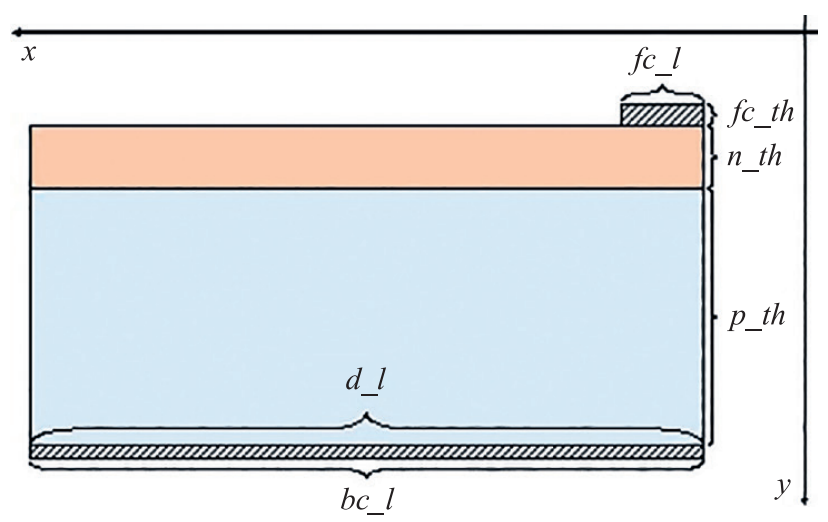

Fig. 1. Simplified structural design of a $p$ - $n$ junction solar cell

To form a $p$ - $n$ junction, the active concentration of trivalent chemical elements in the $p$ field and pentavalent elements in the $n$ field are entered by using the "Constant Profile Placement" dialog box in the "Device" menu. $p-n$ junction and contact regions are meshed smaller than the rest of areas to ensure the accuracy of computing processes. The "Refinement Placement" command in the "Mesh" menu is used to mesh. All of the above processes can also be performed using special commands. The "Scheme Command" window is applied for this task. Although the process is not difficult, it takes much time.

A solution to a more complex problem is required to expand the practical capabilities of the created technological modeling (Fig. 2). It is advisable to take the following structural structures of solar cells: with local $p$-type sections on the back side (Fig. 2,c), with alternating $n$ - and $p$-typical local sections on the back side (Fig. $2, k$ ), with a sinusoidal $p-n$ junction on the front and back sides (Fig. 2, $i, j$ ) and with other structures of $n$ - and $p$-type sections (Fig. 2, $a, b, d, e, f, g, h$, and $l$ ).

It is relatively difficult to create the above-mentioned structures in SDE. Therefore, the coding window of the

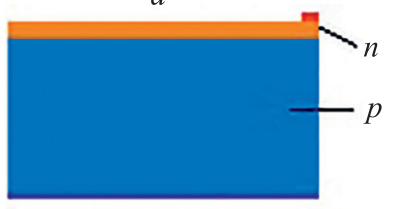

$e$
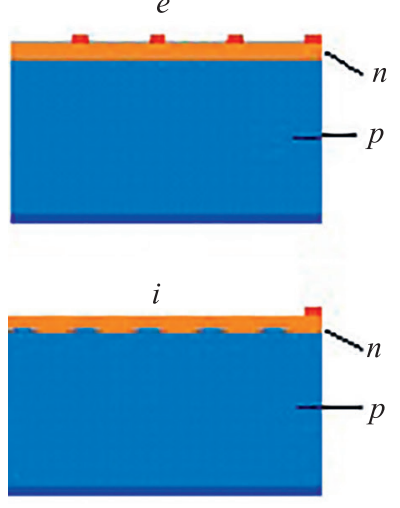

$b$

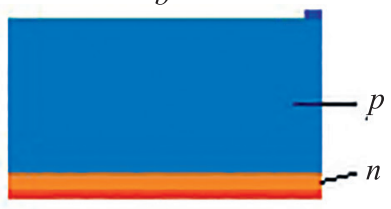

$f$

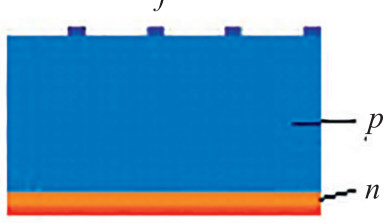

$j$

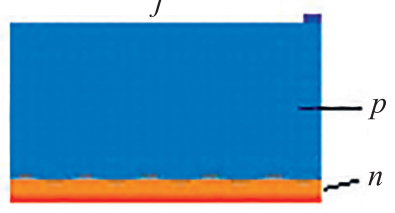

SDE tool in the "Sentaurus WorkBench" framework can be used.

The "Sentaurus WorkBench" package is loaded with a graphical editing window. A new project is created with the menu commands "Project $\rightarrow$ New $\rightarrow$ New Project" or the key combination $\mathrm{Ctrl}+\mathrm{N}$. The SDE tool is added to the project using the "Tool $\rightarrow$ Add" menu command.

Also, in the menu "Parameter $\rightarrow$ Add Parameter/Value" the necessary parameters are added. A two-dimensional Cartesian coordinate system is selected to model the 2D structure of the solar cell. In Fig. 2, the dimensions of the solar cells are the same, but there are some differences in their structure.

Both the variables used in the structure and the initial parameters are determined (Fig. 1). $f_{c} l-$ front contact length, $f c_{-} t h-$ front contact thickness, $n \_t h-n$-type region thickness, $p \_t h-p$-type region thickness, $d \_l-$ cell length, $b c_{-} l-$ back contact length. Several other variables are also introduced to create the solar cell. They are as follows: $f_{c} \_n-$ the number of front contacts, $b c n$ - the number of rear contacts, ordr - the order of placement of $n$ - and $p$-types, project - the ordinal number of the project, mesh — relative mesh size, $b \_c l p-$ the relative proportion of the widths of $n$ and $p$ areas in the structures (Fig. 2, $k, l$ ), deltax and deltay are the difference in steps along the $x$ and $y$ axes in the structures (Fig. 2, $i, j$ ), fnum are the frequencies in the structures (Fig. 2, $i, j$ ).

Note that in this structure, the $x$-axis of the coordinate system is oriented from right to left, and the $y$-axis is oriented from top to bottom.

The "define" statement is used to define variables. For example, if the contact thickness is 0.5 , then the following line is entered:

\section{(define $f c$ th 0.5 ).}

This form of variable identification is an input with exact values. The value can be entered later. So, the first
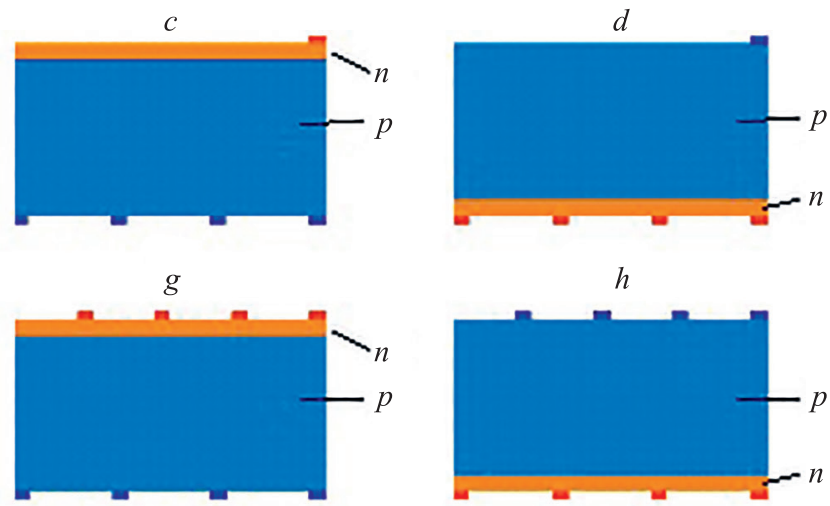

$k$
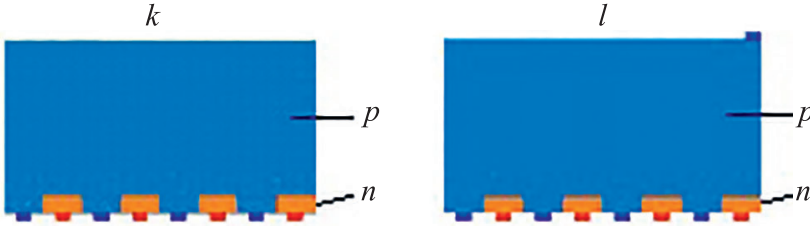

Fig. 2. Structural models of solar cells with different $p-n, n-p$ structures with various contacts In the coding window, the required parameters can be specified for a particular simulation 
parameter with a value is added in the project that was created by "Sentaurus WorkBench" in the previous stage, and this parameter is written between two@ symbols, for example:

(definefcth@Front Contact thickness@).

The following lines should be entered to define other variables shown in Fig. 1:

(define $f c \_t h @$ Front_Contact_thickness@) ; front contact thickness;

(define bc_th@Back_Contact_thickness@) ; rear contact thickness;

(define $f c \_l @$ Front_Contact_length@) ; front contact width;

(definebc_l@Back_Contact_length@) ; rear contact width;

(define $f_{c} \_n @$ Front_contacts@)

(define bc_n@Back_contacts@)

(definen_th@n_type_thickness@)

(define $p \_t h @$ @_type_thickness@)

(defined_l@Device_length@)

(define ordr@Order_p_n@)

(define project “@ProjectNo@”)

(definemesh@Mesh@)

(define $b \_c l p @$ CPercent@)

(definedeltax@dx@)

(definedeltay@dy@)

(definefnum@Frequency@)

When one runs the "Parameter $\rightarrow$ Add Parameter/ menu command, a window for adding a value appears (Fig. 3). If a new parameter is entered in the appeared window, the name of the variable is then written in the "Parameter" field, and the values are entered in the "List of values" field. Besides, in the "Parameter" field, new values are given to the existing parameter by adding values to the "List of values" field.

Note that the records taken as the parameter name must match the requirements of the identifier. So, the parameter name can consist of Latin letters, Arabic numerals, and underscores. For example, if a parameter name consists of two or more words, it cannot be separated with a space. According to the programmers' rules, each word can be

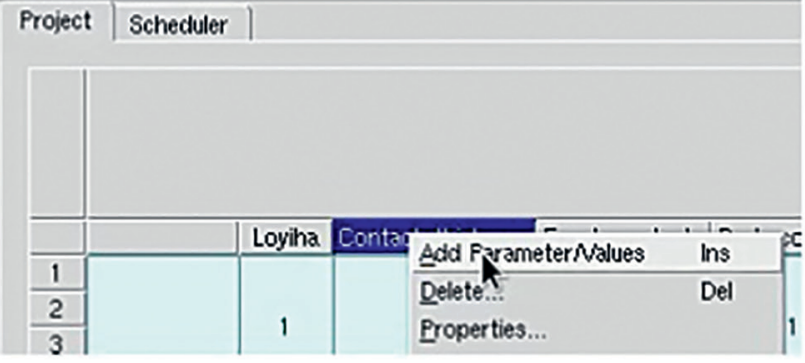

Fig. 3. Menu for adding a parameter or value

capitalized or separated by underscores (but this is not necessary). For example, like FrontContactLength or Front_contact_length.

The variable name can be the same as the parameter name, but it is preferred to use abbreviations to avoid writing in the code window. For instance, the line (define $f_{c} \_l @$ Front_contact_length@) is used to enter Front_contact length as a variable in the code window. The four symbols $f, c$, , and $l$ are used to specify the "Front_contact_length". Some symbols as " " were used in the variable names in order to separate letters. Thus, it is recommended to use an abbreviated version of multiple words as a variable name for its easy writing in the code window.

In most projects, the $p-n$ junction is structured as represented in Fig. 2. it shows that structures $(a)$ and $(b)$ are similar to each other.

In Fig. 2, $a$ the concentration of $\mathrm{p}$ and "anode" contact region is the same and uniform, so the concentration of $n$ and "cathode" contact regions is the same and uniform.

In Fig. 2, $k$ and Fig. 2, $l$, the order of the regions $n$ and $p$ changes, i.e., the top margin is of type $p$ and the bottom margin is of type $n$.

In Fig. 2, c, the concentration is higher in the areas of contact of the cell than the concentration of $n$ and $p$ regions.

In Fig. 2, $g$ and Fig. 2, $h$, the order of $n$ and $p$ changes.

This means that four different situations can be observed in one project.

In projects 1-5 SC, shown in Fig. 2, the front contact, $n$-type (or $p$-type), $p$-type (or $n$-type) and back contact are presented. Depending on their design, the front contact can be single or multiple, and the back contact can also be single or multiple. The structure of these cells can be formed using a single algorithm. Projects can be numbered sequentially with logical values $l 1, l 2$, etc. That is (define $l 1$ (string =? Project " 1 ")). In this case, if the sequence number of the project is 1 , the variable $l 1$ is true; otherwise it takes a false value. Therefore, when forming a structure, a project can be based on a logical operation if the sequence number is $1,2,3,4$ or 5 ( $l 1$ or $l 2$ or $l 3$ or $l 4$ or $l 5)$.

The intersections connecting points $(0,0)\left(0, f_{\mathcal{C}_{-}} t h\right)$, $\left(f c_{-} l, f_{c} \_t h\right)$ and $\left(f c_{-} l, 0\right)$ are created to draw a front contact as shown in Fig. 2. These intersections form a rectangle. A user does not need to enter all points to draw a rectangle. It is enough to take two points corresponding to the diagonal of rectangle as $(0,0)$ and $\left(f_{c} l, f_{c} \_t h\right)$. Now, the following points $\left(0, f_{c} \_t h\right)$ and $\left(d_{-} l, f_{c} t h+n_{-} t h\right)$ are used to form the $n$-type. By entering the coordinates of the $p$-type site $\left(0, f_{c}\right.$ th $\left.+n \_t h\right)$ and $\left(d_{-} l, f_{c} c_{-} t h+n \_t h+p \_t h\right)$ 
and the back contact $\left(0, f_{c}\right.$ th $\left.+n_{-} t h+p_{-} t h\right)$ and $\left(d_{-} l\right.$, $\left.f_{c} t h+n_{-} t h+p_{-} t h+b c_{-} t h\right)$ the structure is formed. The geometric shape formed by these coordinates expresses the design of the SC (Fig. 2, a). Projects for the entered values 2, 3, 4 and 5 can be also created in the same order. The $n$ and $p$ regions are generated similarly. There are differences only in the front and back contacts. Therefore, an algorithm is formed to generate front and rear contacts. The number of front and rear contacts is denoted by the variables $f_{c} \_n$ and $b c \_n$, respectively. To form the number, the parameter $i$ is introduced with an increasing value from 0 to $f_{c} \_n-1$ by one. For the coordinates of the front contact, it is necessary to divide the length of the device by the number of contacts and calculate the coordinates of the contacts by using the following equation:

$$
\begin{gathered}
x_{1}=\frac{d \_l}{f_{c} \_n} \cdot i \\
x_{2}=x_{1}+f_{c} \_l
\end{gathered}
$$

Then the coordinates of the contact $\left(x_{1}, 0\right)\left(x_{2}, f_{c} t h\right)$ are set.

If the value of $f_{c} n$ equal to 1 is chosen, then the number of front contacts will be 1 , then the value of $i$ will take only the value 0 . If the value of $i$ is put to equation (1), it is taken the result as $x_{1}=d_{-} l / f_{c} \_n \cdot 0=0, x_{2}=x_{1}+$ $+f_{c_{-}} l=0+f c_{-} l=f_{c_{-}} l .(0,0)\left(f_{c} \bar{l}_{-}, f_{c_{-}} t h\right)$ can be obtained by setting contact coordinates with $x_{1}$ and $x_{2}$ values. So, the coordinates of the frontal contact indicated in the Fig. 1 were obtained.

The coordinates of the rear metal contact need to be entered. The distance between the contacts should be the same. For example, for creating four contacts, the contact length is determined by dividing the width of the cell by three.

The distance between the contacts can be calculated by using the equation:

$$
d x=\frac{d \_l-b c \_n \cdot b c \_l}{b c \_n-1} .
$$

Note that if the number of contacts is equal to one, this formula is divided by zero. In this case, the formula does not work. Therefore, the condition needs to be added like $b c \_n>1$. In this case, loop is also created, the parameter $i$ is introduced and the coordinates of the contacts are determined by using the equations:

$$
\begin{gathered}
x_{1}=\left(b c \_l+d x\right) \cdot i \\
x_{2}=x_{1}+b c \_l .
\end{gathered}
$$

Since $d x$ is in the equation (2), it cannot be applied to $b c \_n=1$. Therefore, an additional systematic equation is introduced:

$$
d x=\left\{\begin{array}{rl}
\frac{d \_l-b c_{-} n \cdot b c_{-} l}{b c \_n-1}, & b c_{-} n>1 \\
0 & b c_{-} n=1
\end{array},\right.
$$

when $b c_{-} n$ is greater than zero, the coordinates of their location can be obtained by the number of rear contacts.

The rear contact centers are defined by using equations:

$$
\begin{gathered}
x_{3}=x_{1}+\frac{f_{c} l}{2} ; \\
y_{1}=f_{c \_} t h+n_{-} t h+p \_t h+b c \_t h .
\end{gathered}
$$

There is no need to create a separate cycle for contact coordinates. Thus, the commands for drawing the geometric structure of the projects from 1 to 5 were written in the SDE module.

According to the SDE module syntax, arithmetic operations are not written between the elements. For example, if two numbers are added, the expression $a+b$ will be written as $(+a b)$ in the "SDE" module.

For creating the frontal contact and sinusoidal $p-n$ junction in Fig. 2, $i, j$, the script is available in the electronic resources ${ }^{1}$. By entering those scripts into the code window, the common structures for projects $1-5$ can be created. For this, logical value of projects should be equaled to 6 .

The role of gates in the use of these scenarios is crucial. Therefore, Boolean expressions need to be used carefully and correctly. If the logical value of a project is equal to "true", this project will be performed.

\section{Theory}

The semiconductor device is simulated step by step, as it will be easy to simulate if the process is divided into several stages depending on the state of the semiconductor device. There are two main states in semiconductor devices, namely equilibrium and nonequilibrium. If the semiconductor device works in the equilibrium state, it is enough to use the Poison equation and Fermi distribution of carrier to simulate and define the properties of the device. If the semiconductor device works in the nonequilibrium state, the transport of carrier must be taken account by using the continuity equation in addition to the Poison equation and Fermi distribution.

The simulation of solar cells is more complicated than of other semiconductor devices such as diode and transistors due to the light-matter interaction in the solar cells. First, the optical properties of solar cells are calculated. In the Sentaurus Device, mainly three methods are used to calculated optical properties of solar cells: the Transfer Matrix Method (TMM), Ray Tracing Method, and Beam propagation method. This paper uses the TMM, which is given in the equation:

$\left[\begin{array}{c}E_{p, i} \\ E_{p, r}\end{array}\right]=M_{p}\left[\begin{array}{l}E_{p, t} \\ 0\end{array}\right], \quad M_{p}=\left(\begin{array}{ll}M_{p, 11} & M_{p, 12} \\ M_{p, 21} & M_{p, 22}\end{array}\right), \quad\left\{\begin{array}{l}r_{p, t o t}=\frac{M_{p, 21}}{M_{p, 11}} \\ t_{p, t o t}=\frac{1}{M_{p, 11}}\end{array}\right.$, where $M_{p}$ is the transfer matrix; $M_{p, i j}$ is the element of the transfer matrix; $E_{p, i}$ is the electric field of incident light; $E_{p, r}$ is the electric field of reflected light; $E_{p, t}$ is the electric field of transmitted light, $r_{p, t o t}$ is total the Fresnel's reflection coefficient for parallel polarized light, $t_{p, t o t}$ is total

${ }^{1}$ Studying the influence of base thickness on photoelectric parameters of various silicon solar cell with the new TCAD algorithms/ Available at: https://murodjon.uz/article/applications (accessed: 26.08.2021). 
the Fresnel's transmission coefficient for parallel polarized light.

TMM has been mostly used to calculate optical properties of solar cells. One should take into account the interference in the thin film solar cells, and thus the following equation can be used to calculate the reflection, transmission and absorption for each layer and the whole solar cell:

$$
\begin{gathered}
R_{t o t}=\frac{\left(r_{p, t o t}\right)^{2}+\left(r_{t, t o t}\right)^{2}}{2}, \quad T_{t o t}=\frac{n_{3} \cos \gamma_{3}}{n_{0} \cos \beta}\left(\frac{\left(t_{p, t o t}\right)^{2}+\left(t_{t, t o t}\right)^{2}}{2}\right), \\
A_{t o t}=1-R_{t o t}-T_{t o t}
\end{gathered}
$$

where $R_{\text {tot }}$ is the total reflection; $T_{\text {tot }}$ is the total transmission; $A_{\text {tot }}$ is the total absorption; $\beta$ if the angle of incident light; $\gamma$ is the angle of refracted light; $r_{t, t o t}$ is the total Fresnel's reflection coefficient for transversal polarized light and $t_{t, t o t}$ is the total Fresnel's transmission coefficient for transversal polarized light; $n_{0}, n_{3}$ are the refractive indices of media.

The all-calculation methods of optical properties are various combination of the Burger-Lambert law and Fresnel equation.

In the TMM, the Fresnel equations, which are given in the equation, are used as boundary conditions, because they can calculate the optical properties interface between two media:

$$
\left\{\begin{array} { l } 
{ r _ { t } = \frac { n _ { 1 } \operatorname { c o s } \beta - n _ { 2 } \operatorname { c o s } \gamma } { n _ { 1 } \operatorname { c o s } \beta + n _ { 2 } \operatorname { c o s } \gamma } , } \\
{ t _ { t } = \frac { 2 n _ { 1 } \operatorname { c o s } \beta } { n _ { 1 } \operatorname { c o s } \beta + n _ { 2 } \operatorname { c o s } \gamma } }
\end{array} \text { and } \left\{\begin{array}{l}
r_{t}=\frac{n_{1} \cos \gamma-n_{2} \cos \beta}{n_{1} \cos \gamma+n_{2} \cos \beta} \\
t_{p}=\frac{2 n_{1} \cos \beta}{n_{1} \cos \beta+n_{2} \cos \gamma}
\end{array},\right.\right.
$$

where $n_{1}, n_{2}$ are the refractive indices of media; $r_{p}$ is the Fresnel's reflection coefficient for parallel polarized light; $t_{p}$ is the Fresnel's transmission coefficient for parallel polarized light; $r_{t}$ is the Fresnel's reflection coefficient for transversal polarized light; $t_{t}$ is the Fresnel's transmission coefficient for transversal polarized light.

Second, the carrier generation rate has been calculated by using the equation:

$$
G^{o p t}(x, y, z, t)=I(x, y, z)\left[1-e^{-\alpha L}\right],
$$

where $G^{\text {opt }}$ is optical generation; $I$ is light intensity; $L$ is medium thickness; $x, y, z$ are the Cartesian coordinates; $t$ is time; $\alpha$ is the absorption coefficient of medium.

In addition, the Surface, Auger and Shokley-Read-Hall models were used to calculate the recombination rate in the solar cell. The most important kinetic parameter of the carrier, which is mobility, has been calculated by using the Masetti model.

After finding the generation and recombination rates, the electron and holes concentration were calculated by using the Fermi distribution given in the equation:

$$
n=N_{c} F_{1 / 2}\left(\frac{E_{F, n}-E_{c}}{k T}\right) \text { and } p=N_{V} F_{1 / 2}\left(\frac{E_{V}-E_{F, p}}{k T}\right) \text {, }
$$

where $F_{1 / 2}$ is the Fermi half integral; $E_{c}$ is the conduction band energy; $E_{V}$ is the valence band energy; $E_{F, n}$ is the quasi fermi energy for electrons; $E_{F, p}$ is the quasi fermi energy for holes; $T$ is the absolute temperature; $N_{c}$ is the density of states in the conduction band; $N_{V}$ is the density of states in valence band; $k$ is the Boltzmann constant.

The Fermi distribution is a non-analytic function, as it contains the Fermi half integral. By using the Boltzman approximation, the Fermi distribution can be calculated analytically. However, this method has a high relative error. Therefore, in this paper, the Fermi distribution has been calculated numerically.

The Poison equation was then been calculated in order to find the electric field and potential:

$$
\Delta \varphi=-\frac{q}{\varepsilon}\left(p-n+N_{D}+N_{A}\right)
$$

where $\varepsilon$ - the permittivity; $n$ and $p$ - the concentration of electron and holes; $N_{D}$ and $N_{A}$ - the donor and acceptor concentration; $q$ - the electron charge, $\Delta$ is the Laplace operator.

Being a partial differential equation, the Poison equation should be calculated by using numerical methods. It cannot be calculated analytically. During creating the geometric models in the Sentaurus Structure Editor, the solar cell was meshed in order to calculate it by using numerical methods. Relevant mesh sizes are selected to minimize the relative error in the simulating. So, minimum mesh size was $0.01 \mu \mathrm{m}$ and maximum mesh size was $0.02 \mu \mathrm{m}$. Therefore, the relative error has been smaller than $10^{-6}$.

The last stage of the solar cell simulation is defining the carrier transport. As mentioned above, the continuity equation, which is given in the equation, is used to calculate the carrier transport:

$$
\nabla \vec{J}_{n}=q R_{n e t, n}+q \frac{\partial n}{\partial t} \text { and }-\nabla \vec{J}_{p}=q R_{n e t, p}+q \frac{\partial p}{\partial t},
$$

where $R_{n e t, p}, R_{n e t, n}$ are the net recombination of electron and holes; $t-$ time, $\nabla$ is the Del operator, $\vec{J}_{p}$ is the hole current density, $\vec{J}_{n}$ is the electron current density.

In the Sentaurus Device, there are four main different models to calculate the continuity equation: Drift-Diffusion, Thermodynamic, Hydrodynamic and Monte Carlo. In this paper, the Drift-Diffusion model was used to calculate the carrier transport. Moreover, the current is formed due to the carrier transport.

\section{Results and discussion}

The considered calculations and entered codes give results following the exact specified parameters. After all the codes were written and copied into the SDE environment, one can see the geometric structure of the required SC design in a graphical editor (for example, Fig. 4).

In the same way, it is possible to obtain the gradient of the distribution of the concentration of dopants in silicon. By changing the concentration of dopants, it is possible to form $n$-type and $p$-type regions in the shape and size required for research.

The results obtained in the SDE environment can be easily transferred in the form of tdr files to the "Sentaurus Device" simulator. Using the Sentaurus Device, a silicon and composite semiconductor device simulator, one can 


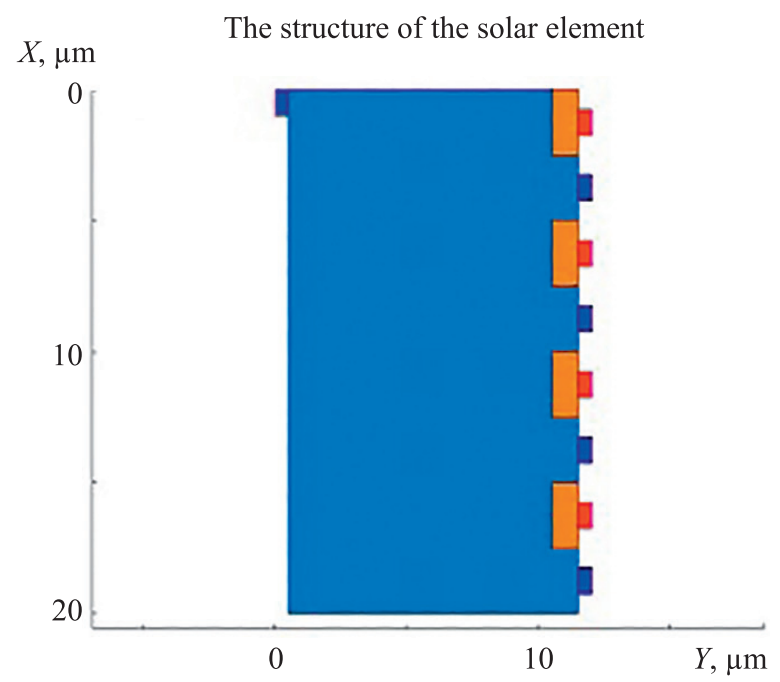

Fig. 4. Geometric structure of a solar cell drawn in the SDE module

simulate the electrical, thermal and optical characteristics of silicon and multi-component semiconductor devices in $2 \mathrm{D}$ and $3 \mathrm{D}$ formats. It supports the development and optimization of modern and functional semiconductor technologies, including nanoscale solar cells, etc. Another "SVisual" tool is TCAD visualization, which provides users with modern interactive 1D, 2D and 3D data visualization. It supports TCL scripting, allowing post-processing of the output to generate new curves and extracted parameters.

The developed algorithm makes it possible to study the SC complexes, which are 6 structural projects with 4 possible particular structural configurations (Table).

The developed algorithm makes it possible to analyze the characteristics of 12 types of SC configurations as shown in the Table. Besides, the projects 1, 3 and 5 are illuminated one side of SC, and the projects 2, 4 and 6 are illuminated double-side of SC. According to [5], to increase the output power of the solar cell, double-sided sensitive structures are used. Then photocurrent was increased two times. One-side illuminated solar cells have flat contact (metal) layers on the back side (the projects 1, 3 and 5). Double-side illuminated solar cells have grid contact (metal) layers both on the front and back sides (the projects 1, 3, and 5). Among the varieties of double-side sensitive $\mathrm{SC}$, the multi-structure on the back side played the main role [6]. In this work, the authors are going to create a high-voltage solar cell with a multi-structure on the rear side [7]. For both one-sided and double-sided sensitive

Table. Some physical properties of silicon SCs simulated in the SDE system with different configurations of the $p-n$ structure and conditions of photosensitivity of the front and back sides

\begin{tabular}{|c|c|c|c|}
\hline $\begin{array}{l}\text { Project } \\
\text { number }\end{array}$ & $\begin{array}{c}\text { Compliance with the } \\
\text { diagrams shown in Fig. } 2\end{array}$ & $\begin{array}{l}\text { The structure of the } p-n \text { junction and local regions } \\
\text { of heavy doping }\end{array}$ & $\begin{array}{l}\text { One- or two-side sensitive } \\
\text { solar cell }\end{array}$ \\
\hline \multirow{4}{*}{1} & \multirow{2}{*}{$a$} & $\operatorname{metal} / p-n /$ metal & \multirow{4}{*}{ One-sided sensitive solar cell } \\
\hline & & $\operatorname{metal} / p^{+}-p-n-n^{+} /$metal & \\
\hline & \multirow{2}{*}{$b$} & metal $/ n-p /$ metal & \\
\hline & & $\operatorname{metal} / n^{+}-n-p-p^{+} /$metal & \\
\hline \multirow{4}{*}{2} & \multirow{2}{*}{$c$} & $\operatorname{metal} / p-n /$ metal & \multirow{4}{*}{ Double-sided sensitive solar cell } \\
\hline & & $\operatorname{metal} / p^{+}-p-n-n^{+} /$metal & \\
\hline & \multirow{2}{*}{$d$} & $\operatorname{metal} / n-p /$ metal & \\
\hline & & $\operatorname{metal} / n^{+}-n-p-p^{+} /$metal & \\
\hline \multirow{4}{*}{3} & \multirow{2}{*}{$e$} & $\operatorname{metal} / p-n /$ metal & \multirow{4}{*}{ One-sided sensitive solar cell } \\
\hline & & $\operatorname{metal} / p^{+}-p-n-n^{+} /$metal & \\
\hline & \multirow{2}{*}{$f$} & metal $/ n-p /$ metal & \\
\hline & & $\operatorname{metal} / n^{+}-n-p-p^{+} /$metal & \\
\hline \multirow{4}{*}{4} & \multirow{2}{*}{$g$} & $\operatorname{metal} / p-n /$ metal & \multirow{4}{*}{ Double-sided sensitive solar cell } \\
\hline & & $\operatorname{metal} / p^{+}-p-n-n^{+} /$metal & \\
\hline & \multirow{2}{*}{$h$} & metal $/ n-p /$ metal & \\
\hline & & $\operatorname{metal} / n^{+}-n-p-p^{+} /$metal & \\
\hline \multirow{4}{*}{5} & \multirow{2}{*}{$i$} & metal $/ p-n /$ metal & \multirow{4}{*}{ One-sided sensitive solar cell } \\
\hline & & $\operatorname{metal} / p^{+}-p-n-n^{+} /$metal & \\
\hline & \multirow{2}{*}{$j$} & metal $/ n-p /$ metal & \\
\hline & & $\operatorname{metal} / n^{+}-n-p-p^{+} /$metal & \\
\hline \multirow{4}{*}{6} & \multirow{2}{*}{$k$} & $\operatorname{metal} / p^{+}-p-n-n^{+} /$metal & \\
\hline & & $\operatorname{metal} / n^{+}-n-p-p^{+} /$metal & \\
\hline & \multirow{2}{*}{$l$} & metal $/ p^{+}-p-n-n^{+} /$metal (rear multi-structure) & \\
\hline & & metal $/ n^{+}-p^{+}-p-p^{+} /$metal (rear multi-structure) & \\
\hline
\end{tabular}


photovoltaic devices, the high advantages of silicon solar cells with a multi-structure on the back side was shown by experiments [8]. To create high-voltage solar cells for using in solar concentrators, it is preferable to use multi-structure solar cells [9].

In the "Sentaurus Workbench" tool, a complete graphical environment can be implemented to create, run and analyze TCAD simulations. Its intuitive graphical interface allows users to navigate and automate common tasks associated with running TCAD simulations, such as managing information flow, including preprocessing custom input files, parameterizing projects, setting up and executing tool instances, and rendering results using appropriate viewers. The "Sentaurus" Devices allow calculating the rate of optical generation both at different wavelengths of light radiation and at different temperatures of the solar cell and connecting it with electrical simulation.

For one-side and double-side illumination, complex algorithmic modeling can be used to calculate the I-V characteristic and to study spectral characteristics of 12 different solar cell designы. Consequently, 12 different designs of solar cells can be studied comprehensively and comparatively. The varying of both geometrical (size and number of micro and macro elements) and physical parameters (doping level, temperature, lifetime and diffusion length of charge carriers) of the SC structures makes it possible to solve multiple problems.

Various structures of solar cells have different photoelectric parameters and properties. The main photoelectric parameters of solar cells are short-circuit current, open-circuit voltage, maximum output power, fill factor and efficiency. In this paper, the dependence of the photoelectric parameters of $p-n$ and $n-p$ junction silicon solar cells, shown in the Fig. 2, $a$ and Fig. 2, $b$, on the thickness of their base has been studied to test the new algorithm. Based on this algorithm, $p-n$ and $n-p$ junction silicon solar cells were created with various thickness of the base.

The short-circuit current increases with the increase of thickness of silicon solar cell. But, there might be a limit for increasing short circuit current depending on its thickness. In this study, we obtained good conditions for silicon solar cell thickness, its short circuit current reaching the maximum

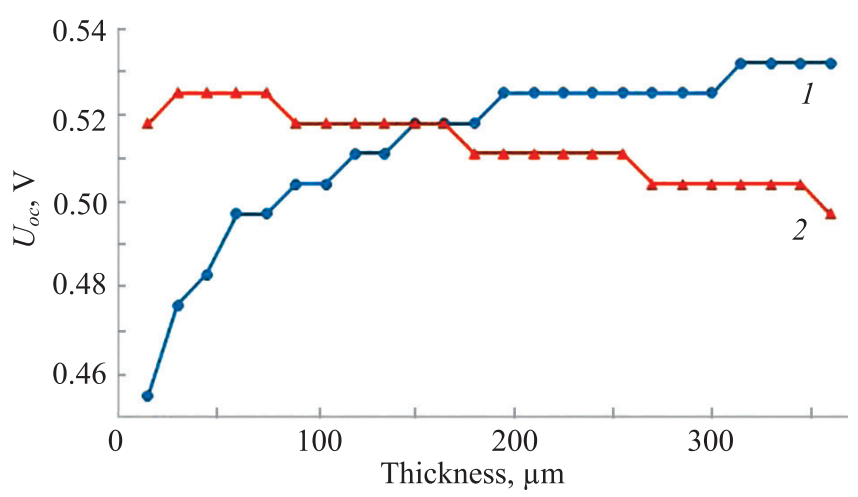

Fig. 5. Dependence of the open circuit voltage of $p-n$ (1) and $n-p(2)$ junction silicon solar cells on thickness of their base value. This function should have its extremum. But, from these obtained results, it was found that a standard $p-n$ junction silicon solar cell has not an extremum point in the range of thickness from $15 \mu \mathrm{m}$ to $360 \mu \mathrm{m}$. So, the short circuit current only increases in this interval. However, the ratio of short circuit current to thickness decreases when thickness increases. When thickness of $p-n$ junction solar cell increased from $15 \mu \mathrm{m}$ to $360 \mu \mathrm{m}$, the short circuit current increased nearly two times. The Tom Tiedjle experiment showed the same result, namely, the short circuit current of $p-n$ junction planar silicon solar cell increased 2.1 times when the base thickness increased from $2 \mu \mathrm{m}$ to $1000 \mu \mathrm{m}$ [10]. The dependence of short circuit current of $n-p$ junction silicon solar cell differed from that of $p$ - $n$ junction. So, there is the extremum point for short circuit current of $n-p$ junction silicon solar cell in the range of thickness from $15 \mu \mathrm{m}$ to $360 \mu \mathrm{m}$. Maximum short circuit current has been observed at $120 \mu \mathrm{m}$ of thickness. In the experimental work, it was found that short circuit current of silicon solar cell decreased to $75 \%$ when the thickness changed from $240 \mu \mathrm{m}$ to 360 $\mu \mathrm{m}$ [11]. The short circuit current decreased over $250 \mu \mathrm{m}$ thick of the base due to the increase of the recombination rate in the base of silicon solar cells.

The absorption coefficient of silicon solar cell is improved due to increase of its base thickness. Various absorption coefficients lead to various generated charge carrier concentration. Photoelectric conversion efficiency solar cells are defined by the external quantum efficiency, which is the ratio of the generated charge carriers concentration to the photon concentration, which is absorbed by the solar cell. Sachenco observed that the increase of silicon solar cell base thickness led to the enhancing of its external quantum efficiency [12]. Changing the charge carrier concentration influences the band gap energy of silicon, as described in the Oschiles's work [13]. In the Polman's theoretical work, the direct dependency between the open circuit voltage and band gap energy was observed [14]. Therefore, open circuit voltage $\left(U_{o c}\right)$ shows dependency on the thickness of solar cell. In the Fig. 5, the dependence of the open circuit voltage of $p-n$ (1) and $n-p$ (2) junction solar cells on their thickness is shown. The open circuit current of $p-n$ junction solar cell increased exponentially depending on base thickness. When the thickness increases from $15 \mu \mathrm{m}$ to $360 \mu \mathrm{m}$, the open circuit voltage increases up to $14.5 \%$. However, the open circuit voltage of $n-p$ junction solar cell decreases to $4 \%$ in this interval. In the Zaki's experiment, the open circuit voltage decreased to $7.9 \%$ in this interval [15]. It means that our obtained results are competitive with experimental works. The high open circuit voltage for $p-n$ junction solar cell was observed at the $30 \mu \mathrm{m}$ of thickness. But in the Barbara Terheiden's experimental work, the open circuit voltage of silicon solar cell, which is covered with optical antireflection coatings and pyramidal textured of its surface, increased to $9 \mathrm{mV}$ when its thickness changed from $100 \mu \mathrm{m}$ to $80 \mu \mathrm{m}$, and even its short circuit current density decreased to $0.3 \mathrm{~mA} / \mathrm{cm}^{2}$ [16].

In using electrical energy generated by solar cells, the MPPT (Maximum Power Point Tracker) is connected to the grid to keep generating the maximum output power [17], while the solar cell generates electrical energy with 

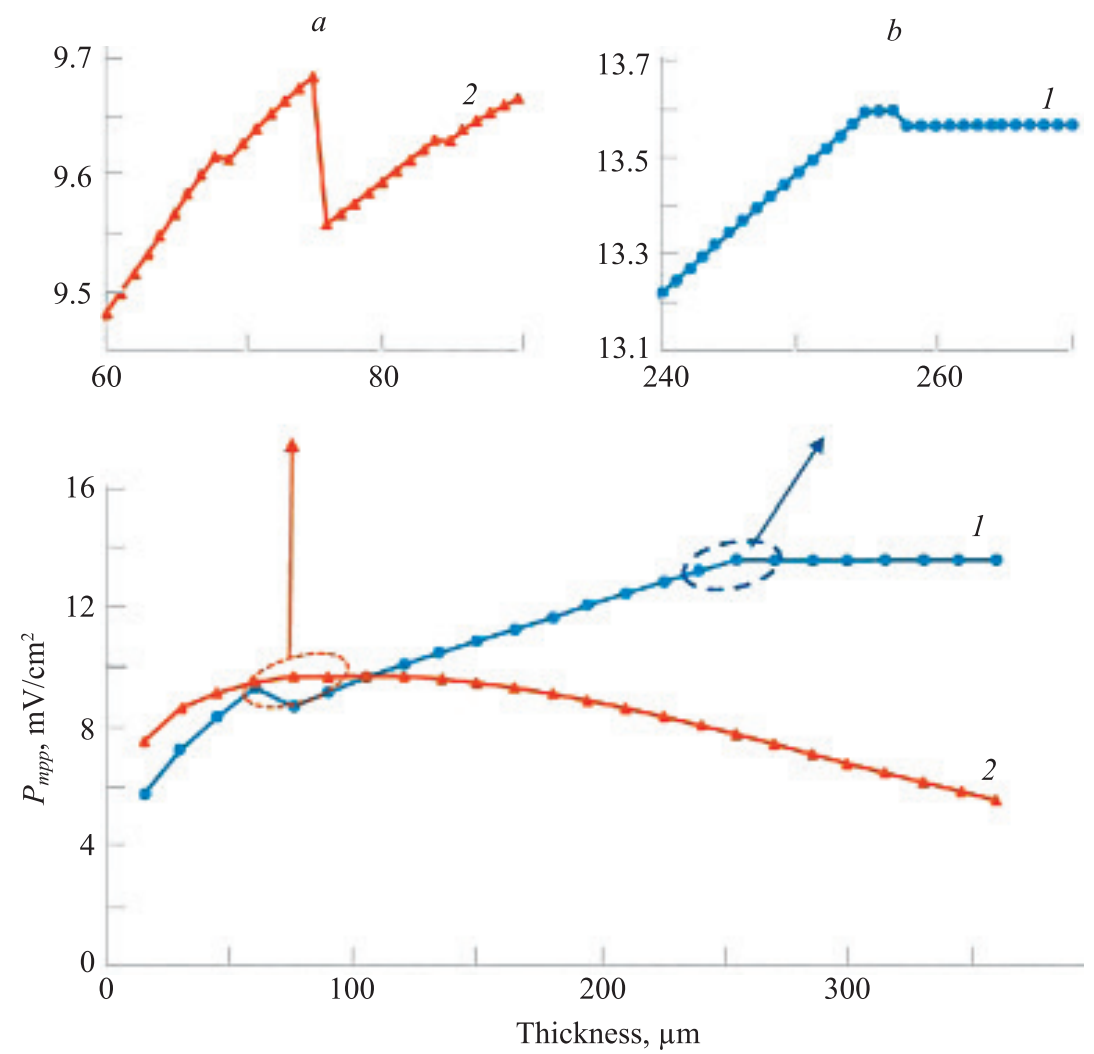

Fig. 6. Dependence of the maximum output power density of $p-n(1)$ and $n-p(2)$ junction silicon solar cells on thickness of their base

various output power. Thus, it is significant to study the maximum output power of solar cells. Fig. 6. shows the dependence of the maximum output power of the $p-n$ (1) and $n-p$ (2) junction silicon solar cell on the thickness of its base. The project has been created twice. The first one was used to simulate with a large step of thickness change to find the interval, which includes the maximum power. In the second work, the solar silicon solar cell was simulated with a small step of thickness change in this interval to find exact silicon solar cell thickness, with which a solar cell reaches the maximum power or maximum efficiency. The thickness with high output power equaled to $256 \mu \mathrm{m}$ for $p$ - $n$ junction solar cell and $75 \mu \mathrm{m}$ for $n-p$ junction solar cell. In the Andrelani's work, it was found the optimum thickness for a silicon solar cell is about $100 \mu \mathrm{m}$ [18]. Besides, in the Jan Hendrik Petermann's experimental work, the conversion efficiency has a broad maximum equal to $20.3 \%$ for a thickness in the $10-50 \mu \mathrm{m}$ range (the experimental value is $19 \%$ for a $43-\mu$ m thick cell) [19]. In the Tool's experimental work [20], the efficiency of the silicon solar cell, which is covered with $\mathrm{SiN}_{\mathrm{x}}$, increased to $1.1 \%$ when the thickness of the base changed from $150 \mu \mathrm{m}$ to $300 \mu \mathrm{m}$. This experimental result is comparable with our simulation results of $p$ - $n$ junction solar cells.

\section{Conclusion}

Thus, by creating a universal algorithm, it is possible to simulate a whole complex of various structures of SC with a $p-n$ junction with a single algorithm. Knowledge of the algorithmic language in the computer simulation of silicon-based SC allows us to use a wide range of structural modeling capabilities.

By varying the commands and elements of a complex algorithmic language, one can build many of the structural elements shown in Fig. 1 into one project with different purposeful controlled physical parameters and their values. This is convenient for both the user and the programming system to significantly reduce the calculation time.

An integrated approach to algorithmic modeling of solar cells makes it possible to calculate their I-V characteristics for one-side and two-side illuminations. Various designs of solar cells can be investigated comparatively.

When producing silicon solar cells, we pay attention to the silicon solar cell thickness, as the efficiencies of solar cells strongly depend on it. The simple $p-n$ and $n-p$ junction silicon solar cell reaches their maximum efficiency $256 \mu \mathrm{m}$ and $75 \mu \mathrm{m}$ of its thicknesses. But if the solar cell is covered with antireflection coatings or textures, included metal nanoparticles, created other materials, the value of optimal thickness will change. 


\section{References}

1. Sentaurus ${ }^{\mathrm{TM}}$ Device User Guide. Version O-2018.06, June 2018.

2. Indrishenok V.I., Pevtcov E.F. Foundations of Process and Device Simulation in Sentaurus TCAD. Moscow, MIREA Publ., 2018, 140 p. (in Russian)

3. Aliev R., Gulomov J., Abduvohidov M., Aliev S., Ziyoitdinov Z., Yuldasheva N. Stimulation of photoactive absorption of sunlight in thin layers of silicon structures by metal nanoparticles. Applied Solar Energy, 2020, vol. 56, no. 5, pp. 364-370. https://doi.org/10.3103/ S0003701X20050035

4. Gulomov J., Aliev R., Mirzaalimov A., Mirzaalimov N., Kakhkhorov J., Rashidov B., Temirov S. Studying the effect of light incidence angle on photoelectric parameters of solar cells by simulation. International Journal of Renewable Energy Development, 2021, vol. 10, no. 4, pp. 731-736. https://doi.org/10.14710/ ijred.2021.36277

5. Juraeva Z. Overview analysis of the main types of solar cells and revealing ways to improve the efficiency and use of solar cells. Universum: tekhnicheskie nauki, 2018, no. 10(55), pp. 66-68. (in Russian)

6. Zaddeh V.V., Pinov A.B., Timerbulatov T.R., Timerbulatov V.T. Tokarev V.E. Structure and method of making silicon photoconverter with two-sided photosensitivity. Paternt RU 2432639. 2011. (in Russian)

7. Aliev R., Gulomov J.J., Mirzaalimov N.A. et.al. Semiconductor photoelectric converter. Patent application no. 20200281. 24.12.2020. (in Russian)

8. Mulligan W.P., Cudzinovic M.J., Pass T., Smith D., Kaminar N., McIntosh K., Swanson R.M. Solar cell and method of manufacture. Patent US 7897867, 2011.

9. Strebkov D.S. Matrix Solar Cells. Vol. 3. Moscow, VIESH Publ., 2010, 348 p. (in Russian)

10. Tiedje T., Yablonovich E., Cody G.D., Brooks B.G. Limiting efficiency of silicon solar cells. IEEE Transactions on Electron Devices, 1984, vol. 31, no. 5, pp. 711-716. https://doi.org/10.1109/TED.1984.21594

11. Plá J.C., Tamasi M.J.L., Bolzi C.G., Venier G.L., Durán J.C. Short circuit current vs cell thickness in solar cells under rear illumination: a direct evaluation of the diffusion length. Solid-State Electronics, 2000, vol. 44, no. 4, pp. 719-724. https://doi.org/10.1016/s00381101(99)00311-1

12. Sachenko A.V., Kostylyov V.P., Bobyl A.V., Vlasyuk V.N., Sokolovskyi I.O., Konoplev G.A., Terukov E.I., Shvarts M.Z., Evstigneev M. The effect of base thickness on photoconversion efficiency in textured silicon-based solar cells. Technical Physics Letters, 2018, vol. 44, no. 10, pp. 873-876. https://doi.org/10.1134/ S1063785018100139

13. Oschlies A., Godby R.W., Needs R.J. First-principles self-energy calculations of carrier-induced band-gap narrowing in silicon Physical Review B, 1992, vol. 45, no. 23, pp. 13741-13744. https:// doi.org/10.1103/physrevb.45.13741

14. Polman A., Atwater H.A. Photonic design principles for ultrahighefficiency photovoltaics. Nature Materials, 2012, vol. 11, no. 3 , pp. 174-177. https://doi.org/10.1038/nmat3263

15. Zaki A.A., El-Amin A.A. Effect of cell thickness on the electrical and optical properties of thin film silicon solar cell. Optics and Laser Technology, 2017, vol. 97, pp. 71-76. https://doi.org/10.1016/j. optlastec.2017.06.009

16. Terheiden B., Ballmann T., Horbelt R., Schiele Y., Seren S., Ebser J., Hahn G., Mertens V., Koentopp M.B., Scherff M., Müller J.W., Holman Z.C., Descoeudres A., De Wolf S., de Nicolas S.M. Geissbuehler J., Ballif C., Weber B., Saint-Cast P., Rauer M., Schmiga C., Glunz S.W., Morrison D.J., Devenport S., Antonelli D. Busto C., Grasso F., Ferrazza F., Tonelli E., Oswald W. Manufacturing $100-\mu \mathrm{m}$-thick silicon solar cells with efficiencies greater than $20 \%$ in a pilot production line. Physica Status Solidi (a), 2015, vol. 212, no. 1, pp. 13-24. https://doi.org/10.1002/pssa.201431241

17. Vitorino M.A., Hartmann L.V., Lima A.M.N., Corrêa M.B.R. Using the model of the solar cell for determining the maximum power poin of photovoltaic systems. Proc. European Conference on Power Electronics and Applications, 2007, pp. 4417684. https://doi. org/10.1109/EPE.2007.4417684

18. Andreani L.C., Bozzola A., Kowalczewski P., Liscidini M., Redorici L. Silicon solar cells: toward the efficiency limits. Advances

\section{Литература}

1. Sentaurus ${ }^{\mathrm{TM}}$ Device User Guide. Version O-2018.06. June 2018.

2. Индришенок В.И., Певцов Е.Ф. Основы приборно-технологического моделирования в Sentaurus TCAD: учебное пособие. M: Московский технологический институт (МИРЭА), 2018. 140 с.

3. Aliev R., Gulomov J., Abduvohidov M., Aliev S., Ziyoitdinov Z., Yuldasheva N. Stimulation of photoactive absorption of sunlight in thin layers of silicon structures by metal nanoparticles // Applied Solar Energy. 2020. V. 56. N 5. P. 364-370. https://doi.org/10.3103/ S0003701X20050035

4. Gulomov J., Aliev R., Mirzaalimov A., Mirzaalimov N., Kakhkhorov J., Rashidov B., Temirov S. Studying the effect of light incidence angle on photoelectric parameters of solar cells by simulation // International Journal of Renewable Energy Development. 2021. V. 10. N 4. P. 731-736. https://doi.org/10.14710/ ijred.2021.36277

5. Жураева 3.И. Обзорный анализ основных видов солнечных элементов и выявление путей повышения эффективности их работы и применения // Universum: технические науки. 2018. № 10(55). С. 66-68.

6. Заддэ В.В., Пинов А.Б., Тимербулатов Т.Р., Тимербулатов В.Т., Токарев В.Е. Конструкция и способ изготовления кремниевого фотопреобразователя с двусторонней фоточувствительностью. Патент RU 2432639. Бюл. 2011. № 30.

7. Алиев Р., Гуломов Ж., Мирзаалимов Н. и др. Полупроводниковый фотоэлектрический преобразователь. Заявка на патент № 20200281. 24.12.2020.

8. Mulligan W.P., Cudzinovic M.J., Pass T., Smith D., Kaminar N., McIntosh K., Swanson R.M. Solar cell and method of manufacture. Patent US 7897867. 2011.

9. Стребков Д.С. Матричные солнечные элементы. Т. 3. М.: ГНУ ВИЭСХ, 2010. 348 c.

10. Tiedje T., Yablonovich E., Cody G.D., Brooks B.G. Limiting efficiency of silicon solar cells // IEEE Transactions on Electron Devices. 1984. V. 31. N 5. P. 711-716. https://doi. org/10.1109/T-ED.1984.21594

11. Plá J.C., Tamasi M.J.L., Bolzi C.G., Venier G.L., Durán J.C. Short circuit current vs cell thickness in solar cells under rear illumination: a direct evaluation of the diffusion length // Solid-State Electronics. 2000. V. 44. N 4. P. 719-724. https://doi.org/10.1016/s00381101(99)00311-1

12. Sachenko A.V., Kostylyov V.P., Bobyl A.V., Vlasyuk V.N., Sokolovskyi I.O., Konoplev G.A., Terukov E.I., Shvarts M.Z., Evstigneev M. The effect of base thickness on photoconversion efficiency in textured silicon-based solar cells // Technical Physics Letters. 2018. V. 44. N 10. P. 873-876. https://doi.org/10.1134/ S1063785018100139

13. Oschlies A., Godby R.W., Needs R.J. First-principles self-energy calculations of carrier-induced band-gap narrowing in silicon // Physical Review B. 1992. V. 45. N 23. P. 13741-13744. https://doi. org/10.1103/physrevb.45.13741

14. Polman A., Atwater H.A. Photonic design principles for ultrahighefficiency photovoltaics // Nature Materials. 2012. V. 11. N 3. P. 174 177. https://doi.org/10.1038/nmat3263

15. Zaki A.A., El-Amin A.A. Effect of cell thickness on the electrical and optical properties of thin film silicon solar cell // Optics and Laser Technology. 2017. V. 97. P. 71-76. https://doi.org/10.1016/j. optlastec.2017.06.009

16. Terheiden B., Ballmann T., Horbelt R., Schiele Y., Seren S., Ebser J., Hahn G., Mertens V., Koentopp M.B., Scherff M., Müller J.W., Holman Z.C., Descoeudres A., De Wolf S., de Nicolas S.M., Geissbuehler J., Ballif C., Weber B., Saint-Cast P., Rauer M., Schmiga C., Glunz S.W., Morrison D.J., Devenport S., Antonelli D., Busto C., Grasso F., Ferrazza F., Tonelli E., Oswald W. Manufacturing 100 - $\mu \mathrm{m}$-thick silicon solar cells with efficiencies greater than $20 \%$ in a pilot production line // Physica Status Solidi (a). 2015. V. 212. N 1. P. 13-24. https://doi.org/10.1002/pssa.201431241

17. Vitorino M.A., Hartmann L.V., Lima A.M.N., Corrêa M.B.R. Using the model of the solar cell for determining the maximum power point of photovoltaic systems // Proc. European Conference on Power Electronics and Applications. 2007. P. 4417684. https://doi. org/10.1109/EPE.2007.4417684

18. Andreani L.C., Bozzola A., Kowalczewski P., Liscidini M., Redorici L. Silicon solar cells: toward the efficiency limits // 
in Physics: X, 2019, vol. 4, no. 1, pp. 1548305. https://doi.org/10.10 80/23746149.2018.1548305

19. Petermann J.H., Zielke D., Schmidt J., Haase F., Rojas E.G., Brendel R. 19\%-efficient and $43 \mu \mathrm{m}$-thick crystalline Si solar cell from layer transfer using porous silicon. Progress in Photovoltaics: Research and Applications, 2012, vol. 20, no. 1, pp. 1-5. https://doi. org/10.1002/pip.1129

20. Tool C.J.J., Burgers A.R., Manshanden P., Weeber A.W., van Straaten B.H.M. Influence of wafer thickness on the performance of multicrystalline Si solar cells: an experimental study. Progress in Photovoltaics: Research and Applications, 2002, vol. 10, no. 4, pp. 279-291. https://doi.org/10.1002/pip.421

\section{Authors}

Murodjon K. Abduvohidov - MSc, Postgraduate, Andijan State University, Andijan, 170100, Uzbekistan, sc 57205282100, https://orcid. org/0000-0002-7598-8565, maueraa@gmail.com

Rayimjon Aliev - D.Sc., Full Professor, Andijan State University, Andijan, 170100, Uzbekistan, Sc 7102561277, https://orcid.org/00000003-1986-2199, alievuz@yahoo.com

Jasurbek Gulomov - Student, Andijan State University, Andijan, 170100, Uzbekistan, sc 57221531752, https://orcid.org/0000-0001-7516987X, jasurbekgulomov@yahoo.com
Advances in Physics: X. 2019. V. 4. N 1. P. 1548305. https://doi.org/ 10.1080/23746149.2018.1548305

19. Petermann J.H., Zielke D., Schmidt J., Haase F., Rojas E.G., Brendel R. 19\%-efficient and $43 \mu \mathrm{m}$-thick crystalline Si solar cell from layer transfer using porous silicon // Progress in Photovoltaics: Research and Applications. 2012. V. 20. N 1. P. 1-5. https://doi. org/10.1002/pip.1129

20. Tool C.J.J., Burgers A.R., Manshanden P., Weeber A.W., van Straaten B.H.M. Influence of wafer thickness on the performance of multicrystalline Si solar cells: an experimental study // Progress in Photovoltaics: Research and Applications. 2002. V. 10. N 4. P. 279291. https://doi.org/10.1002/pip.421

\section{Авторы}

Абдувохидов Муроджон Комилович - магистр, $\mathrm{PhD}$ докторант, Андижанский государственный университет, Андижан, 170100, Узбекистан, sc 57205282100, https://orcid.org/0000-0002-7598-8565, maueraa@gmail.com

Алиев Райимжон - доктор технических наук, профессор, профессор, Андижанский государственный университет, Андижан, 170100, Узбекистан, sc 7102561277, https://orcid.org/0000-0003-1986-2199, alievuz@yahoo.com

Гуломов Жасурбек - магистрант, Андижанский государственный университет, Андижан, 170100, Узбекистан, Sc 57221531752, https:// orcid.org/0000-0001-7516-987X, jasurbekgulomov@yahoo.com

Статья поступила в редакиию 09.08.2021

Одобрена после речензирования 30.08.2021

Принята к печати 27.09.2021

Работа доступна по лицензии

Creative Commons

«Attribution-NonCommercial» 